\title{
Correction: Mandibular reconstruction using an axially vascularized tissue-engineered construct
}

\author{
Ahmad M Eweida ${ }^{*}$, Ayman S Nabawi ${ }^{1}$, Mona K Marei ${ }^{2}$, Mohamed R Khalil ${ }^{1}$ and Habashi A Elhammady ${ }^{1}$
}

\section{Correction}

After publication of this work [1], the authors noted that there were some corrections that should be added to the work. These corrections are done in order to modify some parts that were unfortunately missed during the original publishing procedures. The authors would like to apologize for the inconvenience.

Page 2 in the Methods section under "Mechanical loading studies and design of the defect" line 13: " $4 \mathrm{~cm}$ " should be written instead of " $8 \mathrm{~cm}$."

In the legends of Figures 7 and 8, the right tag should be as follows: A: Parotid duct, D: Facial nerve, V: facial vessels.

\section{Competing interests}

The authors declare that they have no competing interests.

\section{Author details}

${ }^{1}$ Department of Head and Neck and Endocrine Surgery, Faculty of Medicine, University of Alexandria, Alexandria, Egypt. ${ }^{2}$ Tissue Engineering Laboratories, Faculty of Dentistry, University of Alexandria, Alexandria, Egypt.

Received: 22 May 2012 Accepted: 15 June 2012

Published: 15 June 2012

\section{Reference}

1. Eweida, et al: Mandibular reconstruction using an axially vascularized tissue-engineered construct. Ann Surg Innov Res 2011, 5:2.

\section{doi:10.1186/1750-1164-6-4}

Cite this article as: Eweida et al:: Correction: Mandibular reconstruction using an axially vascularized tissue-engineered construct. Annals of Surgical Innovation and Research 2012 6:4.

\footnotetext{
* Correspondence: dr_ae@hotmail.com

1 Department of Head and Neck and Endocrine Surgery, Faculty of Medicine, University of Alexandria, Alexandria, Egypt

Full list of author information is available at the end of the article
}

\section{Submit your next manuscript to BioMed Central} and take full advantage of:

- Convenient online submission

- Thorough peer review

- No space constraints or color figure charges

- Immediate publication on acceptance

- Inclusion in PubMed, CAS, Scopus and Google Scholar

- Research which is freely available for redistribution 